\title{
Infantile Spasms and Down Syndrome: A New Animal Model
}

\author{
MIGUEL A. CORTEZ, LIQING SHEN, YING WU, ILYAS S. ALEEM, CATHERINE H. TREPANIER, HAMID R. SADEGHNIA, \\ ASIM ASHRAF, ASHLIN KANAWATY, CHEN-CHU LIU, LEE STEWART, AND O. CARTER SNEAD III
}

\begin{abstract}
Division of Neurology [M.A.C., O.C.S.]; Department of Paediatrics [M.A.C., O.C.S.]; Neurosciences and Mental Health Program [M.A.C., L.S., Y.W., I.S.A., C.H.T., H.R.S., A.A., AK, C.-C.L., L.S., O.C.S.], Hospital for Sick Children, Toronto, Ontario, Canada M5G 1X8;

University of Toronto [M.A.C., O.C.S.], Toronto, Ontario, Canada M5S 1A1
\end{abstract}

\begin{abstract}
Infantile spasms is a catastrophic childhood seizure disorder for which few animal models exist. Children with Down syndrome are highly susceptible to infantile spasms. The Ts65Dn mouse is a valid model for Down syndrome; therefore, we tested the hypothesis that the Ts65Dn mouse represents a substrate for an animal model of infantile spasms. The baseline of naïve Ts65Dn mice showed spontaneous spike-and-wave discharges, a pattern that worsened with baclofen and $\gamma$-butyrolactone, which induced acute epileptic extensor spasms (AEES) associated with epileptiform polyspike bursts and an electrodecremental response on the EEG. $\mathrm{GABA}_{\mathrm{B}} \mathrm{R}$-agonist-induced AEES were significantly reduced with vigabatrin, rodent $\mathrm{ACTH}$ fragment, valproic acid, ethosuximide, and CGP 35348. Porcine ACTH had no effect. GABA ${ }_{B}$ R protein expression was significantly increased in the thalamus and medulla oblongata of Ts65D mice in comparison with wild-type controls. The $\mathrm{GABA}_{\mathrm{B}} \mathrm{R}$ agonist-treated Ts65Dn mouse shows the unique clinical, electrographic, and pharmacologic signature of infantile spasms and represents a valid, acute model of this disorder. $\mathrm{GABA}_{\mathrm{B}} \mathrm{R}$-mediated mechanisms may contribute to the increased susceptibility of children with Down syndrome to infantile spasms. (Pediatr Res 65: 499-503, 2009)
\end{abstract}

$\mathrm{I}_{\text {o }}^{\mathrm{n}}$ nfantile spasms is an age-specific epilepsy syndrome that occurs in children between the ages of 4 and 12 mo. This disorder is characterized by massive flexor and/or extensor myoclonus and hypsarrhythmia, which is a chaotic EEG recording replete with multifocal spike discharges (1). The spasms are refractory to treatment with most antiepileptic drugs, but exquisitely sensitive to treatment with ACTH or vigabatrin (2-3). Currently, we understand little about the pathogenesis of the seizures in infantile spasms, because there is no valid, standardized animal model that meets all of the criteria set forth for a model of infantile spasms (4-6).

Trisomy 21, or Down syndrome, is the single most common genetic cause of mental retardation (7). The incidence of epilepsy in children with Down syndrome at $8 \%$ is significantly higher than the general population. One-third of those children who have Down syndrome and epilepsy have infantile spasms $(8-10)$. The reasons for the specific association of

Received June 6, 2008; accepted December 4, 2008.

Correspondence: O. Carter Snead III, M.D., Program in Neuroscience and Mental Health, Division of Neurology, 6535 Hill Wing, Hospital for Sick Children, 555 University Avenue, Toronto, ON, Canada M5G 1X8; e-mail: carter.snead@sickkids.ca

Supported by the Bloorview Children's Hospital Foundation (O.C.S.), the Canadian Institutes of Health Research (O.C.S. and M.A.C.), and the Hospital for Sick Children Foundation (M.A.C.).

Supplementary videos are available at http://www.sickkids.ca/sneadlab/. the unique seizure type of infantile spasms with Down syndrome remain unknown.

The most widely studied animal model of Down syndrome is the $\operatorname{Ts}\left(17^{16}\right) 65 \mathrm{Dn}$ (Ts65Dn) mouse $(7,11)$. This mutant mouse is segmentally trisomic for the distal end of murine chromosome 16 (7,12). Although the Ts65Dn mice show Down syndrome-related phenotypes, seizures have not been reported to date in this mouse mutation.

Recently, the Ts65Dn mouse has been reported to overexpress the G-protein-coupled inward rectifying potassium channel subunit 2 (GIRK2) because of the extra gene copy of the Kcnj6/Girk2 gene located within triplicated segments of mouse chromosome 16 in Ts65Dn mouse (13). In addition, a significant increase in $\mathrm{GABA}_{\mathrm{B}}$ receptor-mediated GIRK current was observed in primary hippocampal neurons prepared from Ts65Dn mice (14). $\mathrm{GABA}_{\mathrm{B}}$ receptor agonists are known to induce a unique constellation of seizures in rodents $(15,16)$. Therefore, we reasoned that the Ts65Dn mouse would be uniquely sensitive to the seizure-inducing propensity of $\mathrm{GABA}_{\mathrm{B}}$ receptor agonists given the apparent up-regulation of $\mathrm{GABA}_{\mathrm{B}}$ receptor-mediated currents in these mutant animals. More specifically, we set out to test the hypothesis that the Ts65Dn mouse represents a substrate for an animal model of infantile spasms that would be triggered by $\mathrm{GABA}_{\mathrm{B}}$ receptor agonists.

\section{METHODS}

\begin{abstract}
Animals. This study was approved by the Animal Care Committee at the Hospital for Sick Children (HSC). The Ts65Dn colony was derived from three breeding pairs obtained from Jackson Laboratory (Bar Harbor, Maine) that were housed at the HSC Laboratory Animal Services in Toronto. We maintained the Ts65Dn colony by mating trisomic Ts65Dn females to (C57BL/ 6JEiXC3H/HesnJ) F1 hybrid males in a controlled environment at 12-h light/12-h dark with lights on at $0600 \mathrm{~h}$ and given ad lib access to food and water.

Genotyping. Ts65Dn mice were genotyped by simultaneous quantitative PCR amplification of the amyloid beta precursor protein gene (APP), the myxovirus resistance 1 gene (Mx1), and the apolipoprotein $\mathrm{B}$ (ApoB) as a control gene and comparing the average change (delta) in threshold cycle (CT) between the Ts65Dn genes and the control gene, previously described (17).
\end{abstract}

\footnotetext{
Abbreviations: AEES, acute epileptic extensor spasms; BAC, baclofen, $\mathrm{GABA}_{\mathrm{B}}$ receptor agonist; CGP, CGP 35348, specific $\mathrm{GABA}_{\mathrm{B}}$ receptor antagonist; ECoG, electrocorticographic; EDR, electrodecremental response; ESM, ethosuximide; $\mathbf{G A B A}_{\mathbf{B}} \mathbf{R}$, gamma-aminobutyric acid B receptor; GBL, gamma-butyrolactone; GHB, gamma-hydroxybutyric acid; GVG, vigabatrin; 5-HTP, 5-hydroxytryptophan; NCS, NCS 382, selective GHB receptor antagonist; Ts65Dn, small translocation chromosome 16 symbolized Ts $\left(17^{16}\right) 65 \mathrm{Dn}$; VPA, valproic acid
} 
Drugs. CGP was a gift from Novartis (Basel, Switzerland); baclofen and $\gamma$-butyrolactone (GBL) was obtained from Sigma Chemical Co. (St. Louis, MO). All other chemicals were obtained from standard commercial sources and were of the highest available purification. GBL was administered at the standard dose of $100 \mathrm{mg} / \mathrm{kg} \mathrm{GBL}(n=8)$. BAC at the doses of $0.5,1$, and 2 $\mathrm{mg} / \mathrm{kg}(n=8)$. 5-HTP (the precursor of serotonin) at the doses of 100 and 150 $\mathrm{mg} / \mathrm{kg}(n=8)$. CGP at the doses of 200,100 , and $50 \mathrm{mg} / \mathrm{kg}(n=8)$. VPA at the doses of 100, 200, and $400 \mathrm{mg} / \mathrm{kg}(n=8)$. ESM at the doses of 25,50 , and $100 \mathrm{mg} / \mathrm{kg}(n=8)$. The $\mathrm{ACTH}_{1-39}$ molecule from porcine origin at the doses of 20,40, and $80 \mu \mathrm{g}(n=8)$ and the fragmented form of $\mathrm{ACTH}_{1-24}$ at the doses of 40 and $80 \mu \mathrm{g}(n=8)$. GVG was administered at the doses of 250 and $500 \mathrm{mg} / \mathrm{kg}$.

Surgery. Intraperitoneal administration of pentobarbital at the dose of 35 $\mathrm{mg} / \mathrm{kg}$ provided anesthesia for 1.5 to $2 \mathrm{~h}$. Two frontal and two parietal monopolar epidural electrodes were implanted and secured with dental cement and four screws attached to the parietal regions of the scalp without touching the dura mater. All animals were monitored until complete recovery from anesthesia and then returned to the animal facility for $4 \mathrm{~d}$ with the indication of buprenorphine $0.05 \mathrm{mg} / \mathrm{kg}$ if any signs of pain were detected in the postoperative condition.

Electrocorticographic recordings. All animals were placed in individual, warm Plexiglas (Harvard Apparatus, Holliston, MA) chambers for a 20-min adaptation period before electrocorticography $(\mathrm{ECoG})$ recordings to minimize movement artifact. For those studies in which EDR duration was measured, ECoG recordings from the bilateral frontal and parietal cortices were made on paper using a Grass polysomnograph machine with digital interphase (Grass Instruments, Quincy, MA). In the EEG behavioral and sleep studies, ECoG and behavior were analyzed using an artifact-free EEG video recording system (18). Quantification of AEES was ascertained by visual inspection and under continuous video monitoring of adult $(n=12)$ and developing Ts mice $(n=8)$ and controls $(n=8)$ before and after intraperitoneal treatment with either $100 \mathrm{mg} / \mathrm{kg} \mathrm{GBL}(n=8)$ or BAC $0.5,1$, and $2 \mathrm{mg} / \mathrm{kg},(n=8)$. The brains were harvested for binding experiments of radiolabeled ligands, $\left[{ }^{3} \mathrm{H}\right] \mathrm{CGP} 54626 \mathrm{~A},\left[{ }^{3} \mathrm{H}\right] \mathrm{GHB}$, and $\left[{ }^{3} \mathrm{H}\right] \mathrm{NCS} 382$, and immunoblotting analysis of $\mathrm{GABA}_{\mathrm{B}}$ receptor.

$\boldsymbol{G A B A _ { B }} \boldsymbol{R}$ binding and protein expression. We examined binding of the $\mathrm{GABA}_{\mathrm{B}} \mathrm{R}$ antagonist $\left[{ }^{3} \mathrm{H}\right] \mathrm{CGP} 54626 \mathrm{~A}$ to the $\mathrm{GABA}_{\mathrm{B}}$ receptor as well as the expression of the $\mathrm{GABA}_{B} \mathrm{R}$ protein in the brains of Ts65Dn mice. We also examined the GHB binding site in the brains of the mutant animals $v s$. wild-type controls using both $[3 \mathrm{H}] \mathrm{GHB}$ and $[3 \mathrm{H}] \mathrm{NCS} 382$, an antagonist at the GHB binding site.

Immunoblotting. At $1 \mathrm{mo}$ of age, either Ts65Dn mice or wild-type controls were killed by cervical dislocation and brain cortices were immediately excised, homogenized, and suspended in sample buffer $(62.5 \mathrm{mM}$ Tris-base, $2 \%$ SDS, $10 \%$ glycerol; $\mathrm{pH}$ 6.8). Proteins were then separated with $4-20 \%$ gradient gel by SDS-PAGE, transferred to nitrocellulose membranes, and probed with guinea pig polyclonal anti-GABA(B)R2 (1/1000, Chemicon, Temecula, CA) and mouse monoclonal anti-GAPDH $(1 \mu \mathrm{g} / \mathrm{mL}$, Chemicon) as described elsewhere (19).

Autoradiography of radiolabeled ligands. At 1 mo of age, four pairs of Ts65Dn mice and their littermate control mice were killed by cervical dislocation. Coronal sections were used to perform $\left[{ }^{3} \mathrm{H}\right] \mathrm{CGP} 54626 \mathrm{~A}$, $\left[{ }^{3} \mathrm{H}\right] \mathrm{GHB}$, and $\left[{ }^{3} \mathrm{H}\right] \mathrm{NCS}-382$ autoradiography as described elsewhere (19$23)$. The $\mathrm{pmol} / \mathrm{mg}$ value in each brain region was calculated by interpolation using the image analyzer (24). $t$ test (unpaired and two tailed) was used to analyze the significance in all of the experiments.

\section{RESULTS}

Genotyping. We obtained a gradual increment of Ts65Dn offspring by multiplying the original three breeding pairs of Ts65Dn mice from Jackson Laboratory. The additional breeding pairs were then added to the colony that was maintained by mating trisomic Ts65Dn females and hybrid males, during a 3-yr period. Diploid samples had two copies of both the target gene (APP or Mxl) and the internal control gene (ApoB) (17).

Electrocorticographic, seizure phenotype. Baseline VideoECoG of drug naïve Ts65Dn mice showed intermittent spikeand-wave discharges (SWD) superimposed on slow oscillations, with no behavioral seizures. Next, we administered GBL, a prodrug for the known $\mathrm{GABA}_{\mathrm{B}}$ agonist, GHB. The inactive GBL is converted to GHB by a circulating lactonase
(25). GHB has been shown to produce absence-like seizure activity and induce the kind of electrographic abnormalities observed in the baseline recordings of the Ts65Dn mice (Fig. $1 B$ ). The method of GBL administration is as previously reported (26). In the wild-type mice, $100 \mathrm{mg} / \mathrm{kg}$ GBL resulted in typical rodent absence seizures (Fig. 1C) (26). However, the response of the Ts65Dn mice to this standard absenceinducing dose of GBL was decidedly different from that described earlier for the wild-type mice. Within $20 \mathrm{~min}$ of the administration of the standard GBL dose of $100 \mathrm{mg} / \mathrm{kg}$ to the Ts65Dn mice, the animals showed facial myoclonus and vibrissal twitching; however, this was followed by clusters of AEES associated with bursts of epileptiform activity separated by a marked attenuation of the cortical activity known as EDR (Fig. 1D) on the ECoG. The ECoG in the GBL-treated Ts65Dn mice was reminiscent of a hypsarrhythmic variant with epochs of generalized voltage attenuation reported in children with infantile spasms (24). This phenomenon was

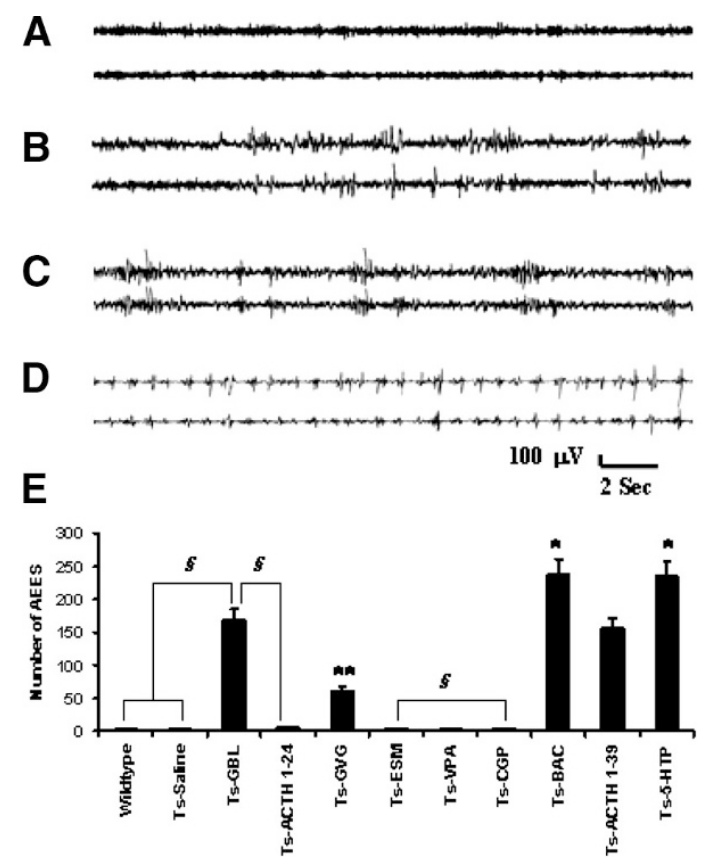

Figure 1. ECoG and pharmacologic effects on the AEES in Ts65Dn mice $(n=8)$. A, ECoG form 2-mo-old wild-type control mice $(n=8)$ showed 35 to $65 \mu \mathrm{V}$ oscillations from the left-right frontal regions (upper panel), and from the left-right parietal regions (lower panel) $(n=8)$. B, ECoG from Ts65Dn mice $(n=8)$ showed spontaneous bilaterally synchronous $5-6 \mathrm{~Hz}$ SWD superimposed on the 35 to $65 \mu \mathrm{V}$ oscillations from the left-right frontal (upper panel) regions and the left-right parietal regions (lower panel). $C$, ECoG after $20 \mathrm{~min}$ of $\mathrm{GBL}(100 \mathrm{mg} / \mathrm{kg})$ test in control mice showed intermittent SWD at the frequency of $7-9 \mathrm{~Hz}$ on the 35 to $65 \mu \mathrm{V}$ oscillations. $D$, ECoG from the frontal and parietal regions after $20 \mathrm{~min}$ of the GBL test in Ts65Dn mice showed frequent EDR associated with a cluster of AEES. Voltage/time scale $=100 \mu \mathrm{V} / 2 \mathrm{~s}$. $E$, Number of AEES after GBL in Ts65Dn mice. AEES are not seen the wild-type-GBL and Ts65Dn-saline groups. In the Ts65Dn group, the number of AEES was reduced with $\mathrm{ACTH}_{1-24}(80 \mu \mathrm{g})$, ESM $(100 \mathrm{mg} / \mathrm{kg})$, VPA $(100 \mathrm{mg} / \mathrm{kg})$, and CGP $(100 \mathrm{mg} / \mathrm{kg})$. There was a partial control of AEES on GVG $(500 \mathrm{mg} / \mathrm{kg})$ and no change was seen with $\mathrm{ACTH}_{1-39}(80 \mu \mathrm{g})$. AEES were exacerbated with BAC $(2 \mathrm{mg} / \mathrm{kg})$ and 5-HTP $(100 \mathrm{mg} / \mathrm{kg}),\left({ }^{*} p<0.05, * * p<0.005, t\right.$ test compared with Ts65Dn group; $\S p<0.0001, t$ test compared with Ts65Dn-GBL group and control group). $\mathrm{EDR}$, electrodecremental response. 
observed in GBL-treated Ts65Dn mice from 1 wk to 2 mo of age irrespective of gender.

AEES associated with epileptiform bursts and EDR reproduced closely the clinical seizure phenotype of infantile spasms (27). Therefore, we studied the response of the AEES and EDR to a panel of antiepileptic drugs (see Methods section). Infantile spasms has a unique pharmacologic profile that dictated the design of these experiments. In this catastrophic epilepsy, the seizures are refractory to classical anticonvulsant drugs, such as phenobarbital, phenytoin, and carbamazepine, but are responsive to VPA, and extremely sensitive to treatment with GVG and ACTH $(2,3)$. In addition, we examined the effect of ESM, a drug is known to abort GBL-induced absence seizures, as well as the CGP and BAC, because GHB is a $\mathrm{GABA}_{\mathrm{B}}$-agonist. Finally, we also tested the response of Ts65Dn mice to 5-HTP, because administration of this compound to patients with Down syndrome has been associated with the occurrence of infantile spasms (Fig. 1E) (28).

We observed a $100 \%$ reduction of EDR and AEES with $\mathrm{ACTH}_{1-24}$ fragment compared with $\mathrm{ACTH}_{1-39}$ (Fig. $2 \mathrm{~A}$ and $B$ ). There was a $65 \%$ reduction of AEES with GVG and a $72 \%$ reduction with CGP (Figs. $1 E$ and $3 A$ and $B$ ). VPA led to a $98 \%$ reduction and was comparable with ESM treatment (Fig. $4 A$ and $B$ ). We observed worsening of AEES and EDR with both BAC and 5-HTP (Fig. 1E) and no change with the porcine form of $\mathrm{ACTH}_{1-39}$ fragment (Fig. 1E) $(p<0.05$, one-way ANOVA). The reduction of GBL-induced seizures by GVG in the GBL-treated Ts65Dn mice was in striking contrast to the response seen in wild-type mice and rats where GVG markedly exacerbated GBL-induced absence-like seizures $(29,30)$.

Ligand binding studies of $G H B$ and $G A B A_{B}$ receptors. We observed no significant difference between Ts65Dn mice and their littermate wild-type controls in radiolabeled GHB, NCS, and CGP54626A binding ( $p$ 0.45) (Data not shown).

Immunoblotting analysis of $G A B A_{B}$ receptor. We detected a strong single band sized $(100 \mathrm{kD})$, consistent with the molecular weight of $\mathrm{GABA}_{\mathrm{B}} \mathrm{R} 2$ and its level of expression

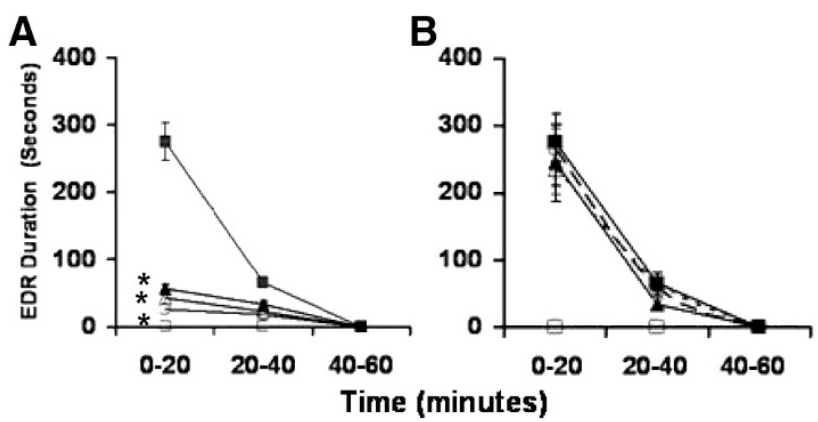

Figure 2. ACTH treatment of AEES. A, Treatment with $\mathrm{ACTH}_{1-24}$ fragment $15 \mathrm{~min}$ before $\operatorname{GBL}(\mathbf{\Delta}), 30 \mathrm{~min}$ before $\operatorname{GBL}(\triangle)$, and $2 \mathrm{~min}$ after GBL $(\bigcirc)$ reduced the EDR duration in Ts65Dn-GBL group (ם) within the first 40 min $(n=6)\left(* p<0.05\right.$, one-way ANOVA). B, ACTH $_{1-39} 20 \mu \mathrm{g} 30 \mathrm{~min}$ before $\operatorname{GBL}(\mathbf{\Delta}), 40 \mu \mathrm{g} 30 \mathrm{~min}$ before $\operatorname{GBL}(\triangle)$, and $80 \mu \mathrm{g} 30 \mathrm{~min}$ before $\operatorname{GBL}(\bigcirc)$ did not change the EDR duration $(n=6),(p=0.5$, one-way ANOVA). A differential response to the ACTH form is observed with porcine fragment ${ }_{1-39}$ vs. rat-human fragment ${ }_{1-24}$ against AEES in the Ts65Dn GBL group (ם). Lack of EDR at baseline in Ts65Dn mice $(\square)$ is represented in $A$ and $B$. EDR, electrodecremental response.

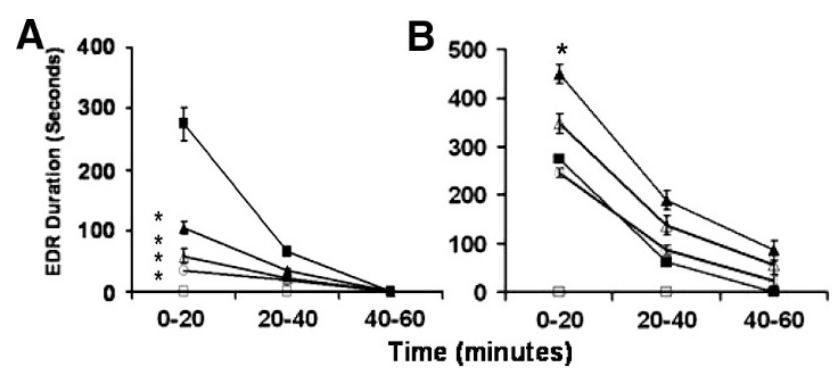

Figure 3. $\mathrm{GABA}_{\mathrm{B}}$ receptor function. A, CGP $50 \mathrm{mg} / \mathrm{kg}(\mathbf{\Delta}), 100 \mathrm{mg} / \mathrm{kg}(\triangle)$, and $200 \mathrm{mg} / \mathrm{kg}(\bigcirc)$ showed a protective effect against the EDR of the Ts65Dn GBL group (ם), $(n=8)(* p<0.05$, one-way ANOVA). $B$, BAC $2 \mathrm{mg} / \mathrm{kg}$ $(\mathbf{\Delta}), 1 \mathrm{mg} / \mathrm{kg}(\triangle)$, and $0.5 \mathrm{mg} / \mathrm{kg}(\bigcirc)$ produced a gradual exacerbation of the EDR duration as a function of the dose, with a worsening of the EDR duration at $2 \mathrm{mg} / \mathrm{kg}$ in the Ts65Dn GBL group (ם) $(n=8),(* p<0.05$, one-way ANOVA). Lack of EDR at baseline in Ts65Dn mice $(\square)$ is represented in $A$ and $B$. CGP, CGP 35348, a specific $\mathrm{GABA}_{\mathrm{B}}$ receptor antagonist; BAC, baclofen; EDR, electrodecremental response.

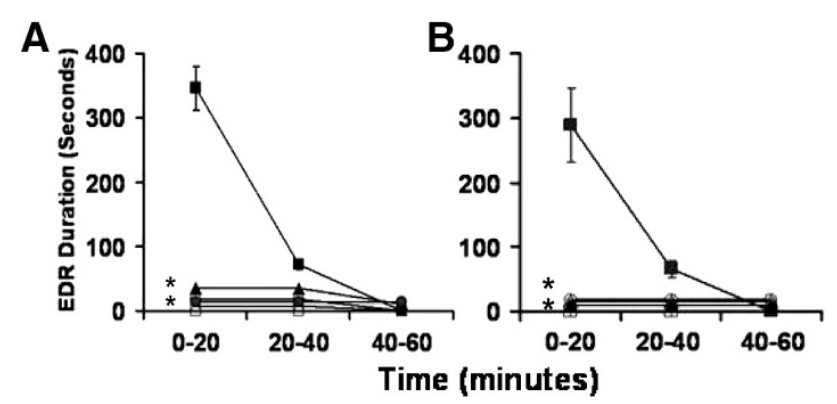

Figure 4. Effect of antiepileptic drugs. A, ESM $50 \mathrm{mg} / \mathrm{kg}(\mathbf{\Delta}), 100 \mathrm{mg} / \mathrm{kg}$ $(\triangle), 200 \mathrm{mg} / \mathrm{kg}(\bigcirc)$, and $400 \mathrm{mg} / \mathrm{kg}(\bigcirc)$ reduced the EDR duration in Ts65Dn-GBL group $(\square)$ in all doses $(n=8)(* p<0.05$, one-way ANOVA). $B$, VPA $400 \mathrm{mg} / \mathrm{kg}(\boldsymbol{\Delta}), 200 \mathrm{mg} / \mathrm{kg}(\triangle)$, and $100 \mathrm{mg} / \mathrm{kg}(\bigcirc)$ reduced the EDR duration in all doses in the Ts65Dn GBL group $(\square)(n=8),\left({ }^{*} p<0.05\right.$, one-way ANOVA). Lack of EDR at baseline in Ts65Dn mice ( $\square$ ) is represented in $A$ and $B$. ESM, ethosuximide; VPA, valproic acid; EDR, electrodecremental response.

was high in neocortex (Ctx), cerebellum (Cbl), thalamus (Tha), and low in medulla oblongata (Med). There was a significant increase of $\mathrm{GABA}_{\mathrm{B}} \mathrm{R} 2$ protein expression in thalamus and medulla oblongata of Ts65Dn mice compared with their littermate control mice in comparison with the expression level of the housekeeping gene, GAPDH, which was a single band sized as $38 \mathrm{kD}$, that has similar expression level in all of the analyzed brain regions. (Fig. $5 A$ and $B),\left({ }^{*} p<0.05, t\right.$ test).

\section{DISCUSSION}

The acute systemic treatment of Ts65Dn mice with a $\mathrm{GABA}_{\mathrm{B}} \mathrm{R}$ agonist results in a phenotype that is reminiscent of infantile spasms, i.e., clusters of AEES associated with EDR on the ECoG, all in developing animals. As well, the $\mathrm{GABA}_{\mathrm{B}} \mathrm{R}$-induced epileptic spasms in Ts65Dn mice show the unique pharmacologic signature of infantile spasms in that they were abolished by both $\mathrm{ACTH}_{1-24}$ fragment and GVG, and exacerbated by 5-HTP. In addition, there appeared to be an increased expression of $\mathrm{GABA}_{\mathrm{B}}$ receptor in the thalamus and brain stem of Ts65Dn mice.

A number of criteria have been suggested for an animal model of infantile spasms to be considered valid. These include age specificity with the seizures being unprovoked and 

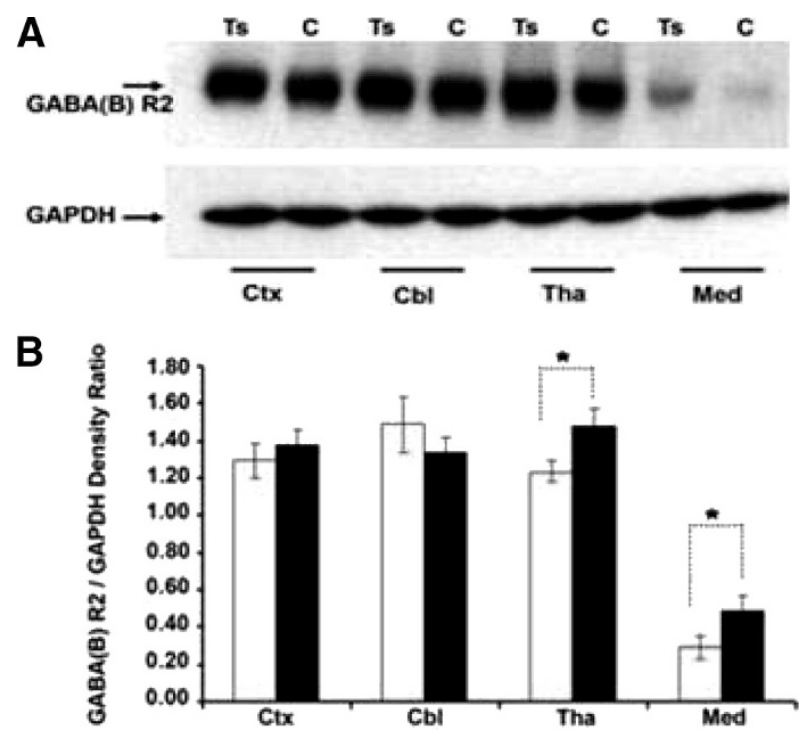

Figure 5. $A, \mathrm{GABA}_{\mathrm{B}} \mathrm{R} 2$ protein expression. Immunoblotting analyses of the expression of $\mathrm{GABA}_{\mathrm{B}} \mathrm{R} 2$ in Ts65Dn (Ts) and their littermate control (C) mice homogenates $(20 \mu \mathrm{g} / \mathrm{lane})$ of neocortex $(\mathrm{Ctx})$, cerebellum $(\mathrm{Cbl})$, thalamus (Tha), and medulla oblongata (Med). With guinea pig polyclonal anti$\mathrm{GABA}_{\mathrm{B}} \mathrm{R} 2$, we detected a strong single band sized $(100 \mathrm{kD})$, consistent with the molecular weight of $G_{A B A} R 2$. The level of expression of $G_{A B A} R 2$ was high in $\mathrm{Ctx}, \mathrm{Cbl}$, Tha, and low in Med. With the mouse monoclonal anti-glyceraldehyde-3-phosphate dehydrogenase (GAPDH), a house-keeping gene, we detected a single band sized $(38 \mathrm{kD})$, similar in all of the analyzed brain regions. $B$, Quantification of the expression level of $\mathrm{GABA}_{\mathrm{B}} \mathrm{R} 2$ based on the ratio between the OD of $\mathrm{GABA}_{\mathrm{B}} \mathrm{R} 2$ and that of GAPDH. There was an increase of $\mathrm{GABA}_{\mathrm{B}} \mathrm{R} 2$ expression in thalamus and medulla oblongata of Ts65Dn mice $v s$. their littermate control mice Data were expressed as mean value $\pm \mathrm{SD}$ from three independent experiments. $\left({ }^{*} p<0.05, t\right.$ test $)$.

more pronounced in developing animals, characteristic semiology (epileptic flexor and/or extensor spasms), an interictal EEG that resembles hypsarrhythmia with ictal EDR, responsiveness to ACTH and vigabatrin, and developmental regression $(4,31)$. Ideally all of these criteria should be present, but models that show only hypsarrhythmia and responsiveness to ACTH without developmental or behavioral correlates would still be quite valuable tools to use in testing hypotheses related to the neurobiology of infantile spasms and its treatment. Our model meets all of these criteria except that the seizures are not spontaneous. As well, we do not yet have the data to comment on whether the $\mathrm{GABA}_{\mathrm{B}} \mathrm{R}$-induced spasms exacerbate the cognitive impairments in the Ts65Dn mouse.

There are other recently reported animal models that manifest some of these essential criteria. Intraperitoneal administration of $N$-methyl-D-aspartic acid (NMDA) to developing rats induces hyperflexion with attenuation of the EEG, but there are neither epileptiform bursts or anything resembling hypsarrhythmia nor do the episodes of hyperflexion respond to ACTH (32). More recently, Velisek et al. (5) reported a putative two hit model of infantile spasms in rat that used prenatal betamethasone exposure as the first hit and systemic administration of NMDA during the second postnatal week as the second hit. The result was flexor spasms with an EEG correlate of high amplitude discharge followed by attenuation; however, ACTH did not eliminate the spasms. Lee et al. (6), using intrahippocampal administration of tetanus toxin in young rats, have reported flexor spasms with an EEG reminiscent of hypsarrhythmia, but report no pharmacologic data on ACTH or GVG in this tetanus toxin model. In our model, $\mathrm{ACTH}_{1-39}$ fragment of porcine origin did not alter the ECoG effect of GBL in Ts65Dn mice. Whether this lack of response is species dependent or molecular weight related is not clear. The Ts65Dn mice model could be a valuable tool for the determination of the differential response of $\mathrm{ACTH}_{1-24}$ and $\mathrm{ACTH}_{1-39}$ fragments against AEES.

The overexpression of $\mathrm{GABA}_{B} \mathrm{R}$ in the Ts65Dn mice in the brain stem would support the involvement of this structure in the generation of infantile spasms in Ts65Dn mice in response to $\mathrm{GABA}_{\mathrm{B}} \mathrm{R}$ agonists as would the exacerbation of the $\mathrm{GABA}_{\mathrm{B}} \mathrm{R}$ agonist-induced spasms by 5 -HT. However, the dramatic response of the Ts65Dn mice to GBL, the suppression of the GBL-induced spasms in the Ts65Dn mouse by $\mathrm{ESM}$, and the increased expression of $\mathrm{GABA}_{\mathrm{B}} \mathrm{R}$ in thalamus of these mutant animals all suggest the involvement of thalamocortical circuitry in infantile spasms in Down syndrome (15). GVG markedly exacerbates $\mathrm{GABA}_{\mathrm{B}} \mathrm{R}$ agonistinduced absence in normal rodents, but has the opposite effect in $\mathrm{GABA}_{\mathrm{B}} \mathrm{R}$ agonist-induced spasms in the Ts65Dn mouse, providing additional evidence that thalamocortical GABAmediated mechanisms may be involved in this phenomenon. The involvement of a perturbed, immature thalamocortical circuitry in the genesis of infantile spasms is in keeping with the data implicating that circuitry in electrographic burst suppression (32). The GABA agonists, BAC and GBL, are effective in producing AEES in Ts65Dn mice as early as $1 \mathrm{wk}$ of age. This effect persists during the prepubescent period and continues into adulthood. We have tested this effect up to 2 mo of age. The exquisite response to GBL in the Ts65Dn mutation leads to a severe alteration of the EEG, such as the EDR. Further studies will be required to follow-up on the EDR in relation to age.

The overexpression of $\mathrm{GABA}_{\mathrm{B}} \mathrm{R}$ in the Ts65Dn mice demonstrated in our experiments also fits with the molecular and functional overexpression of GIRK channels in the Ts65Dn mice $(13,14)$. Taken together these data raise the possibility that $\mathrm{GABA}_{\mathrm{B}} \mathrm{R}$-mediated postsynaptic mechanisms within brain stem and thalamocortical circuitry may play a role in the pathogenesis of infantile spasms in Down syndrome. Alternative hypotheses to explain our data could involve the interaction of the $\mathrm{GABA}_{\mathrm{B}} \mathrm{R}$ with synaptogenesis and dendritic spine formation in the developing brain $(33,34), \mathrm{GABA}_{\mathrm{B}} \mathrm{R}$ modulation of corticotropin-releasing hormone secretion or neurosteroid or melatonin release (35-37) or $\mathrm{GABA}_{\mathrm{B}} \mathrm{R}$ modulation of serotoninergic activity in the raphe (38).

In our acute model, the seizures being neither chronic nor spontaneous constitute a major limitation. However, the data do suggest that the Ts65Dn mouse (39) holds great promise as a substrate for a chronic model to help unravel the pathogenesis of infantile spasms and lead to the identification of novel therapeutic targets for this devastating disorder. There are no published data on the use of ESM in the treatment of infantile spasms; however, the marked efficacy of ESM in this model system suggests that this drug might be efficacious in the treatment of infantile spasms in children with Down syndrome 
(8). Finally, our data suggest that $\mathrm{GABA}_{\mathrm{B}} \mathrm{R}$-mediated mechanisms should be added to the list of putative mechanisms involved in epileptogenesis in infantile spasms (40).

Acknowledgments. The authors thank the HSC Laboratory Animal Services for the Ts65Dn colony care and Marilyn Mclaughlin for assistance in this project.

\section{REFERENCES}

1. Hrachovy RA, Frost JD Jr 2003 Infantile epileptic encephalopathy with hypsarrhythmia (infantile spasms/west syndrome). J Clin Neurophysiol 20:408-425

2. Mackay MT, Weiss SK, Adams-Webber MT, Ashwal S, Stephens DK, BallabanGill K, Baram TZ, Duchowny M, Hirtz D, Pellock JM, Shields WD, Shinnar S, Wyllie E, Snead OC III 2004 Practice parameter: medical treatment of infantile spasms: report of the American academy of neurology and the child neurology society. Neurology 62:1668-1681

3. Lux AL, Edwards SW, Hancock E, Johnson AL, Kennedy CR, Newton RW, O'Callaghan FJ, Verity CM, Osborne JP 2004 The United Kingdom infantile spasms study comparing vigabatrin with prednisolone or tetracosactide at 14 days: a multicentre, randomised controlled trial. Lancet 364:1773-1778

4. Stafstrom CE, Holmes GL 2002 Infantile spasms: criteria for an animal model. Int Rev Neurobiol 49:391-411

5. Velisek L, Jehle K, Asche S, Veliskova J 2007 Model of infantile spasms induced by $N$-methyl-D-aspartic acid in prenatally impaired brain. Ann Neurol 61:109-119

6. Lee CL, Frost JD, Swann JW, Hrachovy RA 2008 A new animal model of infantile spasms with unprovoked persistent seizures. Epilepsia 49:298-307

7. Moore CS, Roper RJ 2007 The power of comparative and developmental studies for mouse models of down syndrome. Mamm Genome 18:431-443

8. Silva ML, Cieuta C, Guerrini R, Plouin P, Livet MO, Dulac O 1996 Early clinical and EEG features of infantile spasms in down syndrome. Epilepsia 37:977-982

9. Stafstrom CE, Konkol RJ 1994 Infantile spasms in children with down syndrome. Dev Med Child Neurol 36:576-585

10. Goldberg-Stern H, Strawsburg RH, Patterson B, Hickey F, Bare M, Gadoth N, Degrauw TJ 2001 Seizure frequency and characteristics in children with Down syndrome. Brain Dev 23:375-378

11. Salehi A, Faizi M, Belichenko PV, Mobley WC 2007 Using mouse models to explore genotype-phenotype relationship in down syndrome. Ment Retard Dev Disabil Res Rev 13:207-214

12. Hattori M, Fujiyama A, Taylor TD, Watanabe H, Yada T, Park HS, Toyoda A, Ishii K, Totoki Y, Choi DK, Groner Y, Soeda E, Ohki M, Takagi T, Sakaki Y, Taudien S, Blechschmidt K, Polley A, Menzel U, Delabar J, Kumpf K, Lehmann R, Patterson D, Reichwald K, Rump A, Schillhabel M, Schudy A, Zimmermann W, Rosenthal A, Kudoh J, Schibuya K, Kawasaki K, Asakawa S, Shintani A, Sasaki T, Nagamine K, Mitsuyama S, Antonarakis SE, Minoshima S, Shimizu N, Nordsiek G, Hornischer K, Brant P, Scharfe M, Schon O, Desario A, Reichelt J, Kauer G, Blocker H, Ramser J, Beck A, Klages S, Hennig S, Riesselmann L, Dagand E, Haaf T, Wehrmeyer S, Borzym K, Gardiner K, Nizetic D, Francis F, Lehrach H, Reinhardt R, Yaspo ML 2000 The DNA sequence of human chromosome 21. Nature 405:311-319

13. Harashima C, Jacobowitz DM, Witta J, Borke RC, Best TK, Siarey RJ, Galdzicki Z 2006 Abnormal expression of the G-protein-activated inwardly rectifying potassium channel 2 (GIRK2) in hippocampus, frontal cortex, and substantia nigra of Ts65Dn mouse: a model of down syndrome. J Comp Neurol 494:815-833

14. Best TK, Siarey RJ, Galdzicki Z 2007 Ts65Dn, a mouse model of Down syndrome, exhibits increased GABAB-induced potassium current. J Neurophysiol 97:892-900

15. Snead OC III, Depaulis A, Vergnes M, Marescaux C 1999 Absence epilepsy: advances in experimental animal models. Adv Neurol 79:253-278

16. Snead OC 3rd $2002 \gamma$-Hydroxybutyric and absence seizure activity. In: Tunnicliff G, Cash CD (eds) Gamma-hydroxybutyrate: Molecular, Functional and Clinical Aspects. London and New York: Taylor \& Francis, pp 132-149

17. Liu DP, Schmidt C, Billings T, Davisson MT 2003 Quantitative PCR genotyping assay for the Ts65Dn mouse model of down syndrome. Biotechniques 35:1170$1174,1176,1178$
18. Moraes MF, Chavali M, Mishra PK, Jobe PC, Garcia-Cairasco N 2005 A comprehensive electrographic and behavioral analysis of generalized tonic-clonic seizures of GEPR-9s. Brain Res 1033:1-12

19. Wu Y, Chan KF, Eubanks JH, Guin Ting Wong C, Cortez MA, Shen L, Che Liu C, Perez Velazquez J, Tian Wang Y, Jia Z, Snead OC III 2007 Transgenic mice over-expressing GABA(B)R1a receptors acquire an atypical absence epilepsy-like phenotype. Neurobiol Dis 26:439-451

20. Snead OC III, Hechler V, Vergnes M, Marescaux M, Maitre M 1990 Increased gamma-hydroxybutyric acid receptors in thalamus of a genetic animal model of petit mal epilepsy. Epilepsy Res 7:121-128

21. Banerjee PK, Hirsch E, Snead OC III 1993 Gamma-hydroxybutyric acid induced spike and wave discharges in rats: relation to high affinity $[3 \mathrm{H}]$ gammahydroxybutyric acid binding sites in the thalamus and cortex. Neuroscience 56:11-21

22. Wu Y, Ali S, Ahmadian G, Liu CC, Wang YT, Gibson KM, Calver AR, Francis J, Pangalos MN, Snead OC III 2004 Gamma-hydroxybutyric acid (GHB) and gammaaminobutyric acid $\mathrm{B}$ receptor (GABABR) binding sites are distinctive from one another: molecular evidence. Neuropharmacology 47:1146-1156

23. Snead OC III 2000 Evidence for a G protein-coupled gamma-hydroxybutyric acid receptor. J Neurochem 75:1986-1996

24. Banerjee PK, Olsen RW, Tillakaratne NJ, Brailowsky S, Tobin AJ, Snead OC III 1998 Absence seizures decrease steroid modulation of $\mathrm{t}[35 \mathrm{~S}]$ butylbicyclophosphorothionate binding in thalamic relay nuclei. J Pharmacol Exp Ther 287:766-772

25. Snead OC III 1991 The gamma-hydroxybutyrate model of absence seizures: correlation of regional brain levels of gamma-hydroxybutyric acid and gammabutyrolactone with spike wave discharges. Neuropharmacology 30:161-167

26. Cortez MA, Perez Velazquez JL, Snead OC III 2006 Animal models of epilepsy and progressive effects of seizures. Adv Neurol 97:293-304

27. Hrachovy RA, Frost JD Jr, Kellaway P 1984 Hypsarrhythmia: variations on the theme. Epilepsia 25:317-325

28. Coleman M 1971 Infantile spasms associated with 5-hydroxytryptophan administration in patients with Down's syndrome. Neurology 21:911-919

29. Snead OC III 1984 Neurotransmitters, seizures and epilepsy. In: Fariello R, Ruggero G (eds) Neurotransmitters, Seizures and Epilepsy, Vol. 2. New York: Raven Press, pp 37-47

30. Bouwman BM, Suffczynski P, Midzyanovskaya IS, Maris E, van den Broek PL, van Riin CM 2007 The effects of vigabatrin on spike and wave discharges in WAG/Rij rats. Epilepsy Res 76:34-40

31. Kabova R, Liptakova S, Slamberova R, Pometlova M, Velisek L 1999 Age-specific $\mathrm{N}$-methyl-D-aspartate induced seizures: perspectives for the west syndrome model. Epilepsia 40:1357-1369

32. Steriade M, Amzica F, Contreras D 1994 Cortical and thalamic cellular correlates of electroencephalographic burst-suppression. Electroencephalogr Clin Neurophysiol 90:1-16

33. Belichenko PV, Kleschevnikov AM, Salehi A, Epstein CJ, Mobley WC 2007 Synaptic and cognitive abnormalities in mouse models of Down syndrome: exploring genotype-phenotype relationships. J Comp Neurol 504:329-345

34. Huang CS, Shi SH, Ule J, Ruggiu M, Barker LA, Darnell RB, Jan YN, Jan LY 2005 Common molecular pathways mediate long-term potentiation of synaptic excitation and slow synaptic inhibition. Cell 123:105-118

35. Brunson KL, Avishai-Eliner S, Baram TZ 2002 ACTH treatment of infantile spasms: mechanisms of its effects in modulation of neuronal excitability. Int Rev Neurobiol 49:185-197

36. Calogero AE, Gallucci WT, Chrousos GP, Gold PW 1988 Interaction between GABAergic neurotransmission and rat hypothalamic corticotropin-releasing hormone secretion in vitro. Brain Res 463:28-36

37. Cullinan WE, Ziegler DR, Herman JP 2008 Functional role of local GABAergic influences on the HPA axis. Brain Struct Funct 213:63-72

38. McGehee DS 2007 GIRK channels as a target for SSRIs. Focus on "reduced 5-HT1A- and GABAB receptors function in dorsal raphe neurons upon chronic fluoxetine treatment of socially stressed rats". J Neurophysiol 98:1-2

39. Davisson MT, Schmidt C, Reeves RH, Irving NG, Akeson EC, Harris BS, Bronson RT 1993 Segmental trisomy as a mouse model for down syndrome. Prog Clin Biol Res 384:117-133

40. Rho JM 2004 Basic science behind the catastrophic epilepsies. Epilepsia 45:5-11 